\title{
Expected Impact of the Introduction of the Leverage Ratio at the Hungarian and EU Level*
}

\author{
Beáta Kocsis - LászlóSeregdi
}

From June 2021, a new set of mandatory requirements will enter into force in the European Union for all credit institutions registered in the EU, specifying in detail the method of calculating the leverage ratio and its minimum level. In this paper, we summarise the main criteria of leverage ratio regulation, the reasons for its introduction and the criticisms that have been expressed. We examine the likely impact of the new requirements as well as the types of credit institutions that may be most affected, and how the leverage ratio relates to different elements of the prudential regulations already in place. Through theoretical and practical examples, we seek to answer the question of when the leverage ratio can become an effective constraint on capital adequacy requirements and for which institutional characteristics it can function as their ideal complement. For this study, we have drawn on the international academic literature on the leverage ratio, analyses by the European Banking Authority and data available from supervisory reporting. We conclude that the leverage ratio in its current form does not have a significant impact on the majority of credit institutions in Hungary, and even at the international level it will primarily only represent an actual constraint for credit institutions which operate with a specific business model and low average risk weights.

Journal of Economic Literature (JEL) codes: E44, E58, G21

Keywords: leverage ratio, banking system, prudential regulation

\section{Introduction}

The idea of introducing a leverage ratio as a minimum requirement emerged after the 2008 global financial crisis. Although similar regulations existed in the past, for example, in Canada and in the USA in the 1990s (Brei - Gambacorta 2014), comprehensive, global standards have not yet been introduced. This is surprising because one of the main reasons for the stricter regulation of banks compared to normal businesses is that, relative to other types of businesses, banks operate with

\footnotetext{
* The papers in this issue contain the views of the authors which are not necessarily the same as the official views of the Magyar Nemzeti Bank.

Beáta Kocsis is a financial modeller at the Magyar Nemzeti Bank. Email: kocsisb@mnb.hu László Seregdi is a supervisory adviser at the Magyar Nemzeti Bank. Email: seregdil@mnb.hu

The Hungarian manuscript was received on 16 March 2021.

DOI: http://doi.org/10.33893/FER.20.2.532
} 
a significantly higher proportion of liabilities, mainly in the form of deposits, i.e. due to the nature of their activities, they operate with high leverage, which also entails higher risk. However, due to the applicable risk weights, so far restriction of the leverage degree has only been partially achieved via the minimum capital adequacy ratio requirements determined as a ratio of own funds to risk-weighted total assets.

Although the capital adequacy ratio regime uses increasingly sophisticated and risksensitive methods to measure whether banks have sufficient own funds to cover their risks, the experience of the global financial crisis demonstrated that some banks were able to build up high leverage even while complying with the capital adequacy ratio. While at the end of the 1990s the average leverage ratio of the 20 largest EU banks was around 6 per cent, by 2008 it had fallen to 3 per cent, i.e. dropped about by half, which in practice meant that the balance sheet total was 32 times the capital. During this period, however, the Tier 1 capital ratio of these same banks remained stable at around 8 per cent, meaning that they were able to achieve this increase in leverage without affecting their risk-weighted capital adequacy level (ESRB 2014). Such an increase in leverage was partly driven by the reduction in capital requirements achieved through the use of internal models, and partly by the issuance of lower quality, Additional Tier 1 instruments. However, during the global financial crisis, it was precisely such highly-leveraged banks that faced financial difficulties. Excessive leverage was also identified as a major factor in the crisis in the Basel Committee on Banking Supervision's report to the $\mathrm{G} 20$ (BCBS 2010), and in the De Larosière Report (De Larosière 2009), which specifically examines the need for changes to the EU regime. The latter particularly stressed that in the case of some institutions, leverage could have been up to 60 times, which made these institutions especially sensitive to changes in the value of assets. If two banks have the same amount of own funds, any change in the value of their assets (e.g. due to provisions or a decrease in the market value of securities) will have a stronger negative impact on the bank operating with higher leverage. Therefore, after lengthy preliminary consultations, in 2014, the Basel Committee proposed the introduction of a leverage ratio, in the calculation of which, risk weights could be applied to assets and off-balance sheet items only in very few cases. Thus, the leverage ratio is less risk-sensitive than the capital adequacy ratio, but when used as an additional, ultimate limit, it can prevent a bank from operating with excessively high leverage.

The Basel Committee's proposal was initially the object of considerable criticism, as - compared to the capital adequacy ratio - the leverage ratio regulation uses a much more primitive calculation methodology and ignores the risk management improvements that banks have achieved over past decades. According to the analogy used by Jeremy Newell (2016), General Counsel of The Clearing House 
Association in the USA, it is like setting the same speed limit for every road in a country, whether it is a highway or a school zone.

Other critics argued that introduction of the leverage ratio will not result in an increase in banks' own funds; moreover, there is a risk that low-risk items (especially retail mortgages) will become much more expensive, or be financed from outside the banking system through securitisation or by other actors, and such a process will result in higher average risk level for exposures remaining with the banking system (Marquardt-Blåvarg 2010), which will weaken financial stability.

If the leverage ratio were used as a stand-alone instrument, these criticisms could be considered valid, but with the introduction of the leverage ratio regime, the Basel Committee does not intend to replace capital adequacy requirements, but rather to complement them (backstop measure). Analysing data from EU banks, ECB staff examined the extent to which criticisms of the leverage ratio are valid in practice, and concluded that introduction of the leverage ratio itself does indeed encourage banks to take higher risks, but the increased capital available from the introduction of the leverage ratio requirement adequately outweighs this negative effect (Smith et al. 2017).

As raising new capital involves costs for banks, it is a logical step for them to invest in higher-yielding but riskier assets. However, they cannot do so indefinitely, as risk-weighted capital adequacy requirements will, sooner or later, prevent further risk-taking. At the same time, banks that are already highly-leveraged will need to raise additional capital to meet the requirement. Overall, therefore, introduction of the leverage ratio promotes a safer banking system.

In another work, Smith also argues in favour of the introduction of the leverage ratio on the grounds, that risk-weighted capital adequacy requirements will always have the shortcoming of basing the degree of risk weights on past experience. These may be wrong for the future (Smith 2020). Risk weights calculated from the models, and even those used in the standardised method, may reveal that actual risks have been underestimated on the basis of past events; but these errors can be adequately offset by the leverage ratio. So far, the main instrument to offset these errors in risk weighting has been the supervisory capital add-on that can be imposed under Pillar 2, but the introduction of the output floor will also serve this purpose in the future (for details, see Section 5.3.3.). 
The EU adopted the Basel recommendation on the leverage ratio with the amendment of CRR, ${ }^{1}$ and accordingly, compliance with the minimum requirement will be mandatory in the EU from 28 June 2021. Thus, the minimum level of the leverage ratio is defined in the EU regulation directly applicable in the member states, i.e. the requirement itself is not specifically defined in the Hungarian legislation. However, since December 2020, the Credit Institutions Act (Hpt.) $)^{2}$ has been complemented by a number of regimes related to the leverage ratio, particularly the rules for determining the supervisory capital add-on and the capital guidance that may be imposed because of the risk of excessive leverage, and the measures to be taken in the event of non-compliance with the leverage ratio buffer requirement.

\section{Calculation of the leverage ratio and the related minimum require- ment}

As with the capital adequacy ratio, the method for calculating the leverage ratio is set out in the CRR. The two types of capital requirement standards are similar in many cases, using similar concepts and calculation procedures (e.g. the leverage ratio also uses the value of T1 capital that is applied to calculate the capital adequacy ratio). However, there are also many important differences between them (see Table 1).

\footnotetext{
${ }^{1}$ Regulation (EU) No 575/2013 of the European Parliament and of the Council of 26 June 2013 on prudential requirements for credit institutions and investment firms and amending Regulation (EU) No 648/2012

${ }^{2}$ Act on Credit Institutions and Financial Enterprises: https://net.jogtar.hu/jogszabaly?docid=a1300237.tv
} 


\begin{tabular}{|c|c|c|}
\hline & Capital adequacy ratio & Leverage ratio \\
\hline $\begin{array}{l}\text { Capital category } \\
\text { used }\end{array}$ & $\begin{array}{l}\text { Three-level: Core Tier } 1 \text { capital, Tier } 1 \\
\text { capital, total own funds }\end{array}$ & $\begin{array}{l}\text { Sets minimum requirement for Tier } 1 \\
\text { capital only }\end{array}$ \\
\hline $\begin{array}{l}\text { Exposure } \\
\text { measurement }\end{array}$ & $\begin{array}{l}\text { Detailed methodology for determining } \\
\text { risk weights, with several methods for } \\
\text { calculating risk weight (e.g. standardised } \\
\text { method, internal models) }\end{array}$ & $\begin{array}{l}\text { Few risk weights can be applied, uniform } \\
\text { calculation methodology }\end{array}$ \\
\hline $\begin{array}{l}\text { Aggregate } \\
\text { exposures }\end{array}$ & Total Risk Exposure Amount & Total Exposure Amount \\
\hline Risks considered & $\begin{array}{l}\text { Credit risk, market risk, operational risk, } \\
\text { settlement risk, CVA }\end{array}$ & $\begin{array}{l}\text { No specific risk categories are defined, } \\
\text { the minimum requirement is relative to } \\
\text { the amount and type of exposures }\end{array}$ \\
\hline $\begin{array}{l}\text { SREP capital } \\
\text { requirement }\end{array}$ & $\begin{array}{l}\text { Under Pillar 2, the micro-prudential } \\
\text { supervisory authority may set an } \\
\text { additional own funds requirement for } \\
\text { any relevant risk }\end{array}$ & $\begin{array}{l}\text { A capital add-on can only be imposed } \\
\text { because of the risk of excessive leverage }\end{array}$ \\
\hline Capital buffers & $\begin{array}{l}\text { Combined macroprudential buffer } \\
\text { requirement (capital conservation, } \\
\text { countercyclical, G-SII, O-SII, systemic risk) }\end{array}$ & $\begin{array}{l}\text { For the time being, the minimum } \\
\text { leverage ratio requirement will only } \\
\text { increase for G-SIls (but later this may } \\
\text { also apply to O-SIIs) }\end{array}$ \\
\hline
\end{tabular}

Credit institutions are already required to report to the supervisory authority on a quarterly basis the current value of their leverage ratio, calculated in accordance with the current text of the CRR. The new rules on the leverage ratio in CRR2 ${ }^{4}$ will take effect from June 2021 and, in several respects, clarify the rules used so far to calculate total exposure. The changes typically clarify the range of exposures to be taken into account in the calculation, the way they are calculated and introduce new exemption rules. These changes, therefore, mostly only alleviate the requirements, as they allow for the reduction of the total exposure amount for more assets or off-balance sheet items. Most of the changes made in CRR2 are aimed at alignment with the Basel III recommendation.

Based on the nature of the changes, for Hungarian institutions it can be stated that the current leverage ratio values calculated and reported under the pre-CRR2 rules will not be materially affected by the new regulations.

The Basel guidelines and the CRR2 set the minimum leverage ratio at 3 per cent of the Tier 1 capital. In order to make the leverage ratio and the capital adequacy

\footnotetext{
${ }^{3}$ The risk of excessive leverage, as defined in Article 4(1)(94) of the CRR, means 'the risk resulting from an institution's vulnerability due to leverage or contingent leverage that may require unintended corrective measures to its business plan, including distressed selling of assets which might result in losses or in valuation adjustments to its remaining assets'.

${ }^{4}$ Regulation (EU) 2019/876 of the European Parliament and of the Council of 20 May 2019 amending Regulation (EU) No 575/2013
} 
ratio comparable, this minimum level was defined in a similar way to the capital adequacy ratio, i.e. as the ratio between the Tier 1 capital and the total exposure amount. In practice, this can still lead to interpretation difficulties, as traditional approaches have generally interpreted the leverage ratio as the liabilities/capital ratio. In this approach, the higher the value, the higher the leverage, i.e. the riskier the operation of the institution. However, due to the peculiarities of the Basel and CRR calculation method, this is reversed; thus, similarly to the capital adequacy ratio, the higher the value of the leverage ratio, the more capitalised the institution, i.e. the lower the degree of leverage.

The total exposure amount determined as the denominator of the leverage ratio is significantly different from the total risk exposure amount used in the calculation of the capital adequacy ratio. In calculating the total exposure amount, all assets and off-balance sheet items are to be taken into account at 100 per cent value, except those included in Table 2.

\section{Table 2}

\section{What should and should not be taken into account in total exposure}

Assets

- Assets that have been deducted in the calculation of Tier 1 capital (e.g. intangible assets, investments) may be disregarded

- Assets should be taken into account at their value less impairment and prudent valuation

- Credit risk mitigation factors (collaterals, guarantees) should not be taken into account in determining the value of assets, except for certain pre-financing or bridging loans (e.g. loan secured by building-society savings)

- Exposures to a parent company, a subsidiary, a sister company may be exempted upon the approval of the supervisory authority

- Article 429a of the CRR2 also lists other exposures that may be exempted, e.g. guaranteed parts of export credits, the trade exposures of the institution to a qualifying central counterparty, fiduciary assets, certain exposures to central banks

\begin{tabular}{l|l}
\hline Off-balance sheet items \\
$\begin{array}{l}\text { Off-balance sheet } \\
\text { items in Annex I to } \\
\text { CRR }\end{array}$ & $\begin{array}{l}\text { The exposure amount should be calculated according to Article 111(1) of the } \\
\text { CRR, in a manner similar to the calculation of the capital adequacy ratio, except } \\
\text { that a credit conversion factor of } 10 \text { per cent rather than zero should be applied } \\
\text { to low-risk off-balance sheet items }\end{array}$ \\
\hline $\begin{array}{l}\text { Derivative } \\
\text { transactions }\end{array}$ & $\begin{array}{l}\text { For derivative transactions, the exposure amount under CRR2 should now be } \\
\text { calculated with the newly introduced Standardised Approach for Counterparty } \\
\text { Credit Risk }\end{array}$ \\
\hline $\begin{array}{l}\text { Securities financing } \\
\text { transactions }\end{array}$ & $\begin{array}{l}\text { In the case of securities financing transactions (repo, securities lending), the } \\
\text { additional risk due to counterparty credit risk must be taken into account }\end{array}$ \\
\hline $\begin{array}{l}\text { Credit derivatives } \\
\text { sold }\end{array}$ & $\begin{array}{l}\text { For sold credit derivatives, in addition to the counterparty credit risk of the trans- } \\
\text { action, there is an additional credit risk due to a possible change in the credit } \\
\text { quality of the underlying asset, and this risk must also be added to the total } \\
\text { exposure amount }\end{array}$ \\
\hline
\end{tabular}




\section{Leverage ratio data at EU and Hungarian level}

In its annual Risk Assessment Report, the European Banking Authority (EBA) has also performed a detailed analysis of data from 162 banks covering 80 per cent of the EU banking system. Data on the capital adequacy ratios and leverage ratios of these banks and similar data for credit institutions operating in Hungary are presented in Figure 1.

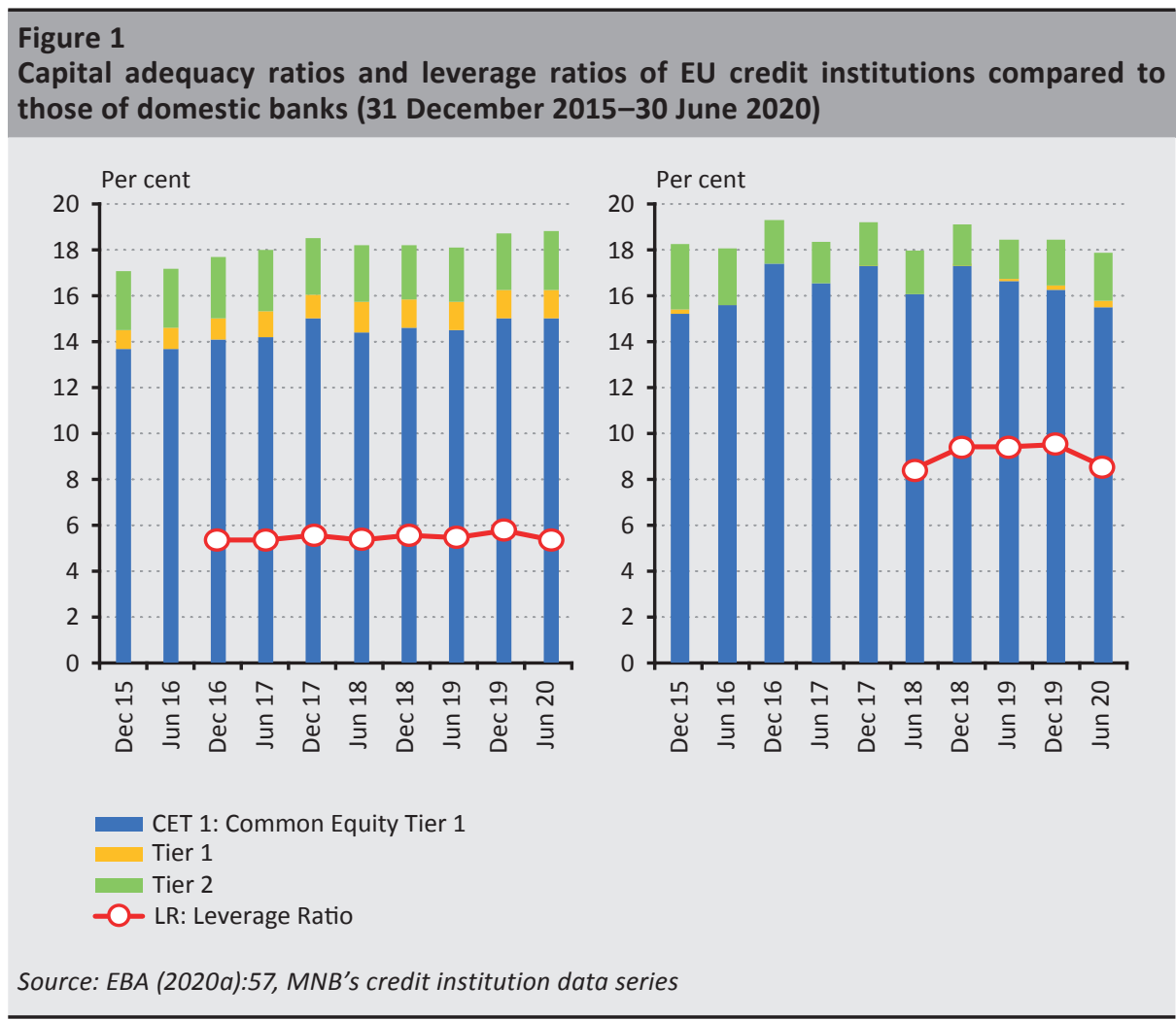

Figure 1 also shows that capital adequacy ratio and leverage ratio do not necessarily move together. While at the EU level, there is a clear increase in the total and Core Tier 1 capital ratios, the leverage ratio is essentially stagnating with small fluctuations. Compared to this, domestic data show a difference in that Hungary has a very low ratio of additional Tier 1 capital relative to the EU average, but some comovement can already be observed in the capital adequacy ratio and leverage ratio.

A closer look at the EU banks' leverage ratio data also reveals that there is quite a wide variability in the leverage ratios of individual banks (Figure 2). 


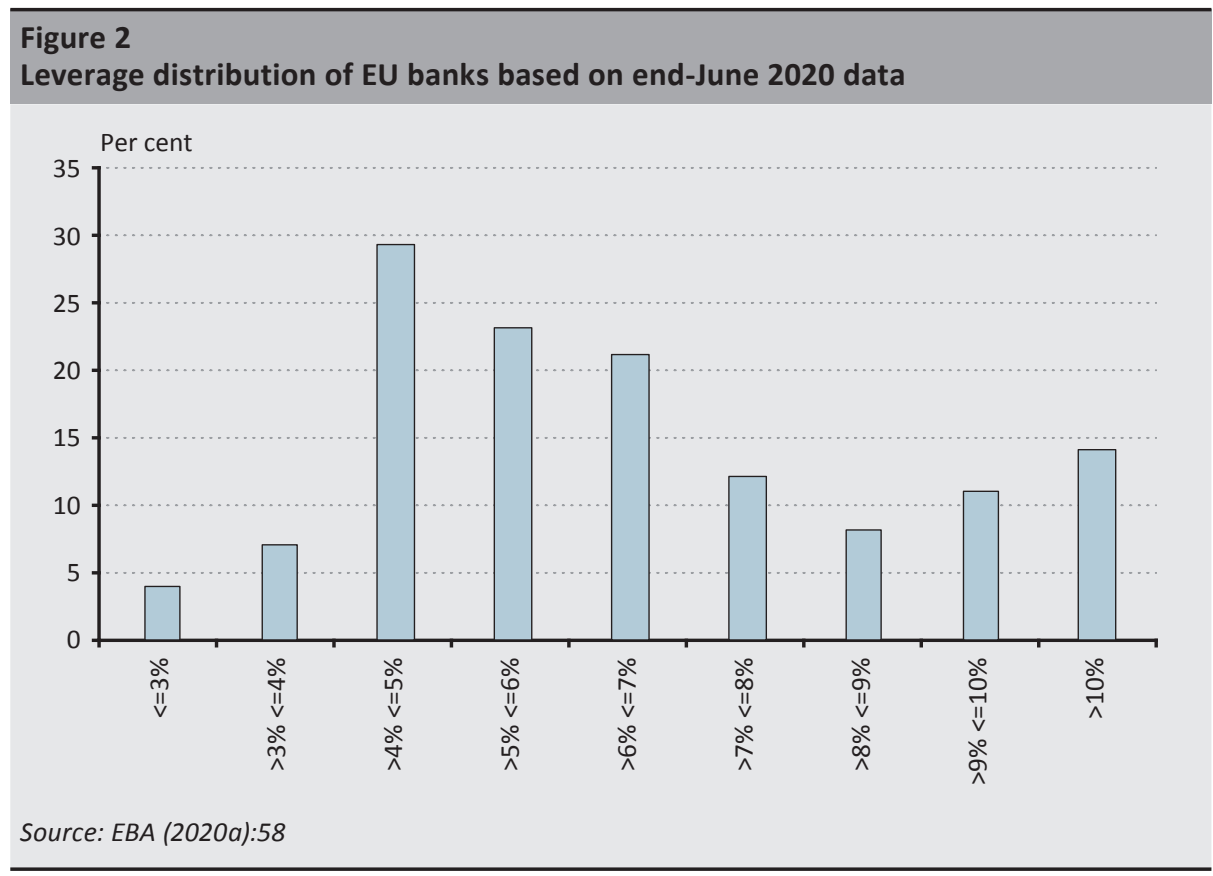

Looking at the Hungarian data at the aggregate level, the values of the capital adequacy ratio and the leverage ratio are broadly in line, but there are a number of individual banking data where these values move in the opposite direction of each other. In addition to the increase and relative stagnation of the capital adequacy ratio, the leverage ratio is decreasing for banks 2,4 and 18 , while the opposite trend is observed for bank 6 (Figure 3).

There can be many reasons for inconsistent movements; without being exhaustive, let us take a few theoretical examples (Figure 4). If the institution invests its new funds (e.g. deposits) in low-risk assets (e.g. government securities), the capital adequacy ratio will show a minimal decrease or remain at the same level due to the low risk weight, while the leverage ratio will deteriorate significantly as it considers the total exposure amount. If the share of Tier 2 capital items within the own funds increases significantly at the expense of Tier 1 capital items, this will also cause a deterioration in the leverage ratio, with the capital adequacy ratio remaining unchanged as it takes into account the total capital. 


\section{Figure 3 \\ Evolution of capital adequacy and leverage ratios (2018 Q2-2020 Q3)}

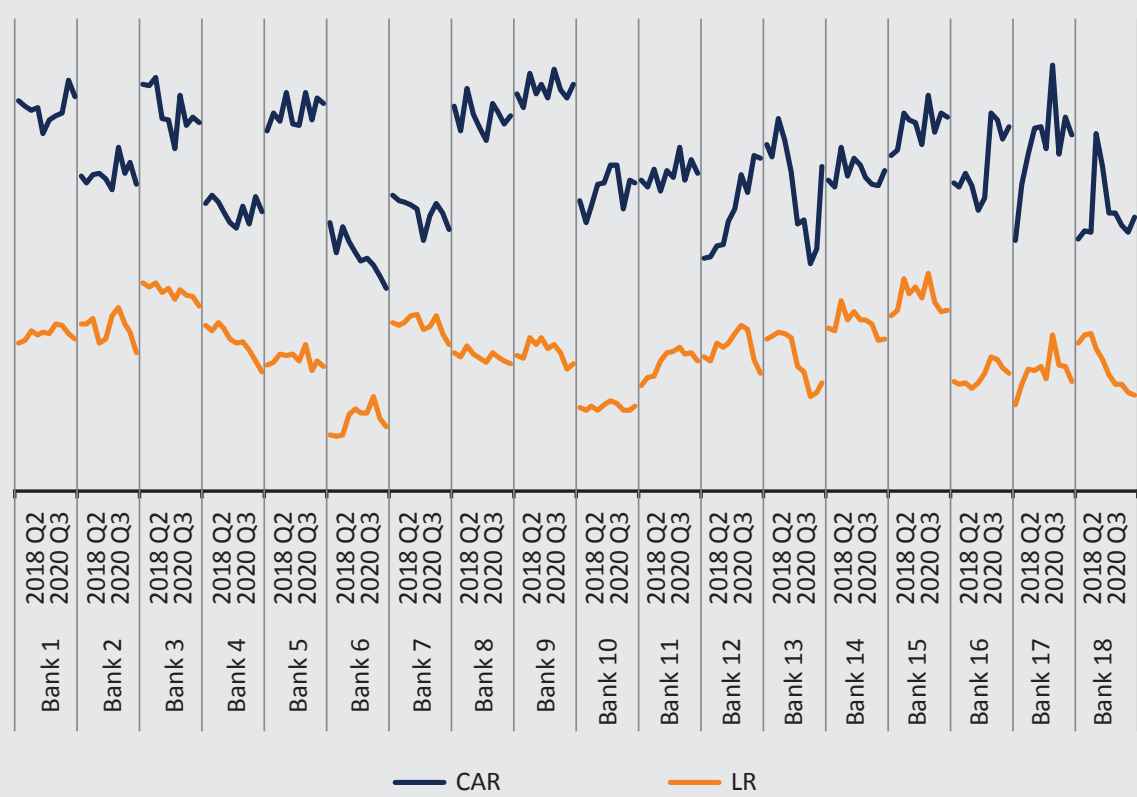

Note: To avoid identification, banks reporting outlier values are not shown in the figure. The exact values are not provided for data protection reasons, and the numbering of banks is different in the different figures.

Source: MNB, supervisory reporting

Figure 4

Examples of 'co-non-movements' of capital adequacy and leverage ratios

\begin{tabular}{|c|ccc|}
\hline \multicolumn{1}{|c|}{ Assets } & Liabilities & Assets & Liabilities \\
\hline $\begin{array}{c}\text { Government bonds } \uparrow \\
\text { Other assets }\end{array}$ & $\begin{array}{c}\text { Deposits } \uparrow \\
\text { Other liabilities }\end{array}$ & $\begin{array}{c}\text { Government bonds } \\
\text { Other assets }\end{array}$ & $\begin{array}{c}\text { Tier } 2 \text { capital } \uparrow \\
\text { Tier } 1 \text { capital } \downarrow\end{array}$ \\
\hline
\end{tabular}




\section{Leverage ratio as an effective constraint}

Due to its simplified approach which ignores risk weights, the leverage ratio can be an ideal complement to the more complex, risk-sensitive framework of the capital adequacy ratio. Depending on the risk profile of the institutions, one of the two methodologies typically represents a stronger constraint, setting a higher minimum capital requirement. Regarding the capital required, the two sets of requirements are equal for a theoretical threshold, which can be called the critical average risk weight (Kenaissi-Gimpelewicz 2017).

The definition of the critical average risk weight can be derived through the example of a theoretical $A B C$ bank. Let us assume that $A B C$ bank has no Pillar 2 capital requirement and is not subject to any macroprudential capital buffer requirement other than the capital conservation buffer (CCB). Now, let us further assume that the exposure amount used to calculate the leverage ratio (LR) and the capital adequacy ratio (CAR) is the same, i.e. it has no exposures that would require or justify an additional requirement, a different valuation methodology or netting in the calculation of the leverage ratio compared to the capital adequacy ratio. In this simplified world, the minimum capital required under the leverage ratio methodology is 3 per cent of the total exposure, while for the capital adequacy, the minimum capital is determined by the total exposure amount multiplied by the average risk weight and by 8.5 per cent ${ }^{5}$ (Kenaissi - Gimpelewicz 2017).

$$
\begin{aligned}
\text { Leverage capital requirement } & =3 \% \cdot \text { Total exposure } \\
\text { Capital adequacy capital requirement } & =8,5 \% \cdot \text { Total exposure } \cdot R W^{*}
\end{aligned}
$$

$$
\text { Critical } R W^{*}=3 \% / 8,5 \%=35,3 \%
$$

The critical average risk weight, which is the boundary between the two frameworks, will then be 35.3 per cent. If the institution's average risk weight remains above 35.3 per cent, the minimum capital required is determined by the fulfilment of capital adequacy requirements, upon fulfilment of which the 3 per cent minimum level of leverage ratio is automatically met. The leverage ratio becomes an effective constraint only below 35.3 per cent, at which point the higher capital requirement arises from meeting the 3 per cent limit (Figure 5).

\footnotetext{
${ }^{5}$ For the sake of comparability with the leverage ratio, only the capital adequacy for Tier 1 capital is considered. Under the CRR, the required minimum capital adequacy is 8 per cent; for T1 capital, 75 per cent of it, i.e. 6 per cent, plus a capital conservation buffer of 2.5 per cent.
} 


\section{Figure 5 \\ Effective boundary of the leverage ratio}

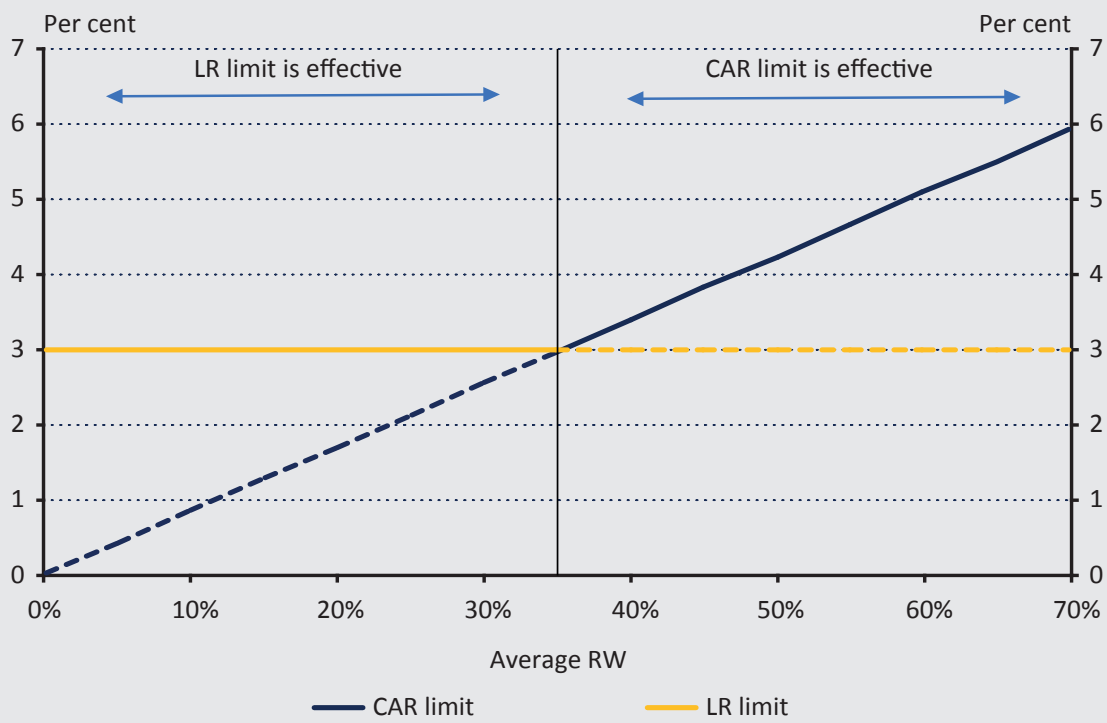

Note: In the figure, lending activity financed from sources other than Tier 1 capital, while maintaining an unchanged asset mix, represents a downward shift.

Source: Compiled on the basis of Kenaissi - Gimpelewicz (2017)

If we assume that the value of non-CCB buffers in the Hungarian banking sector ranges between 0 and 12 per cent, ${ }^{6}$ of which $\mathrm{O}-\mathrm{SII}$ is $0-2$ per cent ${ }^{7}$ and capital guidance (P2G) (in the absence of publicly available data, hypothetically) is 0-10 per cent, and if we also assume a value between 0 and 10 per cent for Pillar 2 capital requirements (public data are also not available here), then, based on the above, the critical average risk weight will be between 10.7 and 35.3 per cent (Figure 6).

${ }^{6} \mathrm{CCyB}=0 \%$, SyRB $=0 \%$

https://www.mnb.hu/en/financial-stability/macroprudential-policy/the-macroprudential-toolkit/ instruments-to-contain-the-risks-of-excessive-credit-growth/countercyclical-capital-buffer

${ }^{7}$ https://www.esrb.europa.eu/pub/pdf/other/esrb.notification200827_osii_hu 617159d05f. en.pdf?62f74467cb59547c01409f286788b2aa 


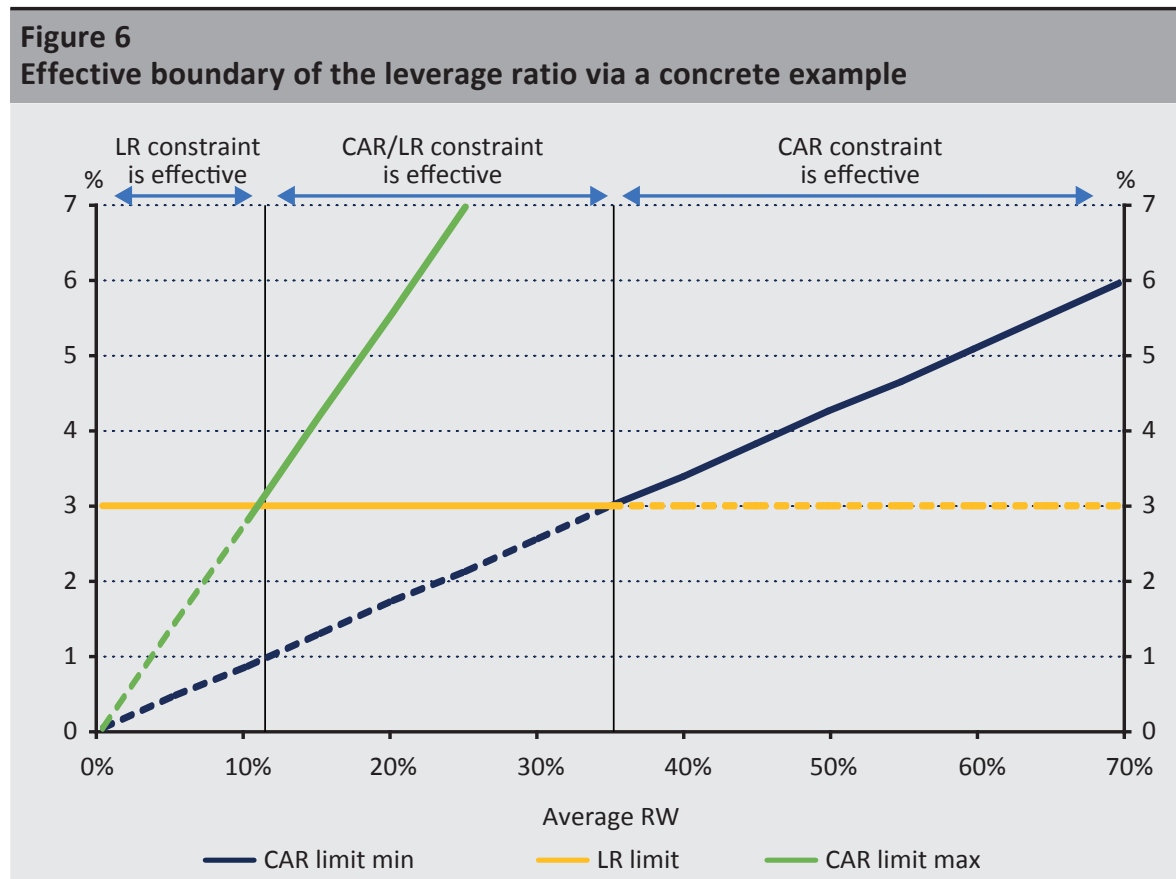

Source: Compiled on the basis of Kenaissi - Gimpelewicz (2017)

The calculated average risk weight refers to the total risk-weighted exposure amount, but from this the credit risk weight can also be estimated. In the Hungarian banking sector, the credit risk ratio within the total capital requirement is 86 per cent, ${ }^{8}$ and thus the leverage ratio can become effective below a level of approximately 30 per cent for the risk weight of an average credit risk, ${ }^{9}$ subject to our assumption that the above exposure amounts are the same. In the Hungarian banking sector, the average credit risk weight calculated according to this method is currently higher than this; in the period 2018-2020, it was above 43 per cent in each quarter. Although there were several values of around 20-30 per cent in the period under review for the group-level banking data, an average credit risk weight representing a lower effective constraint usually applies in these cases, due to additional buffer requirements (P2G, P2R, O-SII) on Tier 1 capital, and thus the minimum required level of leverage ratio, with the capital adequacy ratio, represents a real constraint in few cases.

\footnotetext{
${ }^{8}$ By the end of 2019: https://www.mnb.hu/en/supervision/time-series/i-financial-institutions/creditinstitutions

${ }^{9}$ In this case, the calculation of the average credit risk weight: (credit risk RWA)/(exposure amount used in the calculation of the leverage ratio). It should be noted that, due to the assumption of equal exposure amounts, in the denominator, the credit risk exposure in the general sense was not taken into account.
} 
Looking for empirical evidence of the leverage ratio becoming effective, we examined the relationship between Tier 1 capital adequacy, ${ }_{10}^{10}$ the leverage ratio and the average risk weight we defined, over the time series already used before (2018 Q2-2020 Q3). We calculated the degree to which individual institutions exceed the absolute minimum of the capital adequacy requirement for Tier 1 capital (6 per cent) and the leverage ratio requirement of 3 per cent, and then compared the difference between the two ratios with the average credit risk weight. If the outperformance ratio with regard to the capital adequacy ratio for a given institution is significantly higher than the excess ratio regarding the leverage ratio, then the leverage ratio is expected to be an effective constraint sooner, and the institution is in the positive quadrant of the vertical axis. Experience has shown that the lower the average credit risk weight of an institution, the more likely this is (Figure 7).

To illustrate this using an example: if, with respect to Tier 1 capital, an institution has a capital adequacy ratio of 9 per cent and a leverage ratio of only 3 per cent, it is constrained by the leverage ratio requirement, and in Figure 7 , it is on the line $y$ $=0.5$ (since $9 / 6-3 / 3=0.5$ ). According to the observed data, the lower the average credit risk weight of an institution, the more likely this is.

\section{Figure 7 \\ Capital adequacy and leverage ratios for Tier 1 capital in relation to average credit risk weight in the Hungarian banking sector (2018 Q2-2020 Q3)}

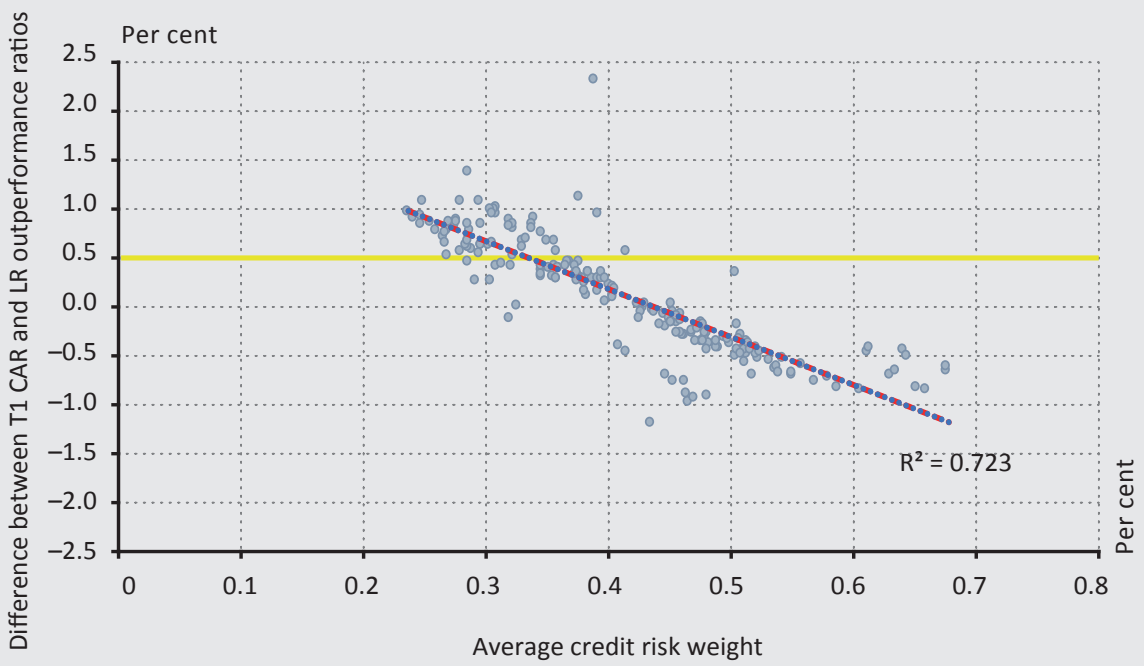

Note: The authors have taken care to preserve anonymity in the presentation. T1 CAR: capital adequacy for Tier 1 capital, calculation of y values (T1 CAR/6\%) - (LR/3\%)

Source: $M N B$, supervisory reporting, quarterly data for credit institutions registered in Hungary

${ }^{10}$ As before, the reason for choosing adequacy for Tier 1 capital is that only Tier 1 capital can be taken into account in the leverage ratio. 
If the total capital adequacy ratio was used instead of the Tier 1 capital requirement, the correlation would be affected by the Tier 2 capital proportion, which can only be taken into account in the case of total capital adequacy. For banks with the same parameters (own funds, RWA, leverage ratio exposure, average credit risk weight), the higher the Tier 2 capital proportion within the own funds, the lower the leverage ratio will be, making it even more likely that the leverage ratio will be breached sooner relative to the capital adequacy ratio. However, Figure 7 would be distorted by the heterogeneity of the Tier 2 capital ratio across banks and the different capital concept of leverage and total capital adequacy ratio, so the correlation would be less clear.

The leverage ratio can become an effective constraint primarily if the bank's internal model used in the calculation of Pillar 1 capital requirement assigns extremely low credit risk weights to exposures, and the bank has significant amounts of government securities or principally low-risk assets based on its business model. In many cases, mortgage banks, building societies and other individual institutions with a special business model fall far below the average credit risk weight of 30 per cent mentioned above, and thus in their case the leverage ratio is most likely to become effective. The role of the business model is discussed in detail in Section 5.5.

In light of the above, the minimum leverage ratio requirement is currently set at such a low level that it only creates an actual constraint in special cases for banks that are engaged in services considered low risk by the capital adequacy rules. During the EU Parliament's debate on CRR2, which introduced a minimum of 3 per cent, there were many proposals for amendments, which would have set the floor significantly higher (the highest proposal was for a 10 per cent minimum).

Although the Basel Committee voted in favour of the 3 per cent minimum in its proposal, and this has been adopted by the $\mathrm{EU}$, there are quite different views on determining the optimal value for the minimum requirement. Studies on this issue take the view that an equilibrium value must be found, at which the benefits of a higher leverage ratio are equal to the resulting higher costs.

The benefits of a higher leverage ratio primarily include a reduction in the likelihood of a banking crisis, the quantification of which depends on factors such as the impact of the banking crisis on reducing a country's GDP or the persistence of the impact. As for the costs of a higher leverage ratio, the point here is that, as a result, banks have to have more capital, which makes their funding costs more expensive, and this is reflected in the pricing of the services they offer. Such studies determine the optimal leverage ratio at levels well above 3 per cent, falling in the range of 8-21 per cent, depending on the variables included in the calculations (Barth-Miller 2018). 
In light of these studies, it may seem surprising to set the minimum requirement at 3 per cent, but the main reason for this is that the Basel Committee intends to use the leverage ratio only as an additional instrument for the capital adequacy ratio. If we look at the regulation of the capital adequacy ratio, it is clear that, since its introduction in 1988, the regulation has undergone a number of tightening measures, including, in particular, additions regarding market and operational risk, the Pillar 2 capital requirement, capital buffers, tightening of the conditions for instruments that can be taken into account in own funds or the increase in the share of CET1 capital within own funds. Therefore, over the longer term, it is quite possible that leverage rules will also be tightened if the leverage ratio is shown to be an effective instrument in preventing banking crises. How the higher leverage ratio requirement imposed by supervisory authorities due to the risk of excessive leverage will work and the extent to which it can be standardised will be crucial in this respect. The future evolution of the leverage ratio regulation may also be affected by how banks react when it becomes an effective constraint, because from a financial stability point of view - it makes a difference whether banks reduce their risks on the assets side, e.g. by selling securities or loans (deleveraging), or raise new capital in order to achieve compliance.

\section{Other important issues related to the leverage ratio}

\subsection{Basel III finalisation, introduction of the G-SII capital buffer, exposures to central banks}

At the end of 2017, the Basel Committee amended the Basel III recommendation in relation to a number of points, including changes to the rules for calculating the leverage ratio (BCBS 2017). Most of the changes have no significant impact and are mainly of a technical nature, including the manner in which derivatives are included in the total exposure amount and alignment of the exposure amount calculation of off-balance sheet items with the risk weights used in the calculation of the capital adequacy ratio. However, there were also some changes with a more significant impact, in particular the imposition of the $\mathrm{G}-\mathrm{SII}^{11}$ leverage capital buffer and the possibility to exempt exposures to central banks.

The leverage ratio buffer requirement is half the size of the G-SIl systemically important capital buffer. In practice, this means that if, for example, a G-SII has a G-SIl capital buffer requirement of 1 per cent, the minimum leverage ratio will be 3.5 per cent instead of 3 per cent. In the event of non-compliance with the leverage ratio buffer, the G-SIl shall restrict payments (dividends, variable remuneration) in the same way as in the case of non-compliance with the combined buffer requirement. The impact of the G-SIl leverage ratio buffer requirement is illustrated

\footnotetext{
${ }^{11}$ G-SII: Global Systemically Important Institutions
} 
in the figure below for a G-SII with a G-SII capital buffer requirement of 1 per cent. For such a bank, the minimum CET1 capital adequacy ratio requirement consists of the Pillar 1 minimum capital requirement ( 4.5 per cent), the capital conservation buffer requirement (2.5 per cent) and the G-SII capital buffer requirement (1 per cent), i.e. a total of 8 per cent. The minimum leverage ratio requirement will increase by half of the 1 per cent G-SII capital buffer requirement, so it will be $[3+(1 \times 50 \%)=] 3.5$ per cent.

\section{Table 3}

Capital conservation ratios applicable in the event of non-compliance with CET1 capital adequacy ratio and leverage ratio

\begin{tabular}{c|c|c}
$\begin{array}{c}\text { CET1 Capital adequacy } \\
\text { ratio }\end{array}$ & Leverage ratio & $\begin{array}{c}\text { Minimum capital conservation ratios } \\
\text { (as a percentage of earnings) }\end{array}$ \\
\hline $4.5-5.375 \%$ & $3-3.125 \%$ & $100 \%$ \\
\hline$>5.375-6.25 \%$ & $>3.125-3.25 \%$ & $80 \%$ \\
\hline$>6.25-7.125 \%$ & $>3.25-3.375 \%$ & $60 \%$ \\
\hline$>7.125-8 \%$ & $>3.375-3.50 \%$ & $40 \%$ \\
\hline$>8.0 \%$ & $>3.50 \%$ & $0 \%$ \\
\hline
\end{tabular}

Source: BCBS (2017)

Table 3 shows that if the bank in the example has a leverage ratio of 3.3 per cent, it shall restrict its dividend-like or variable-remuneration-like payments. The detailed rules on the restriction of payments are set out in the $C R D^{12}$ and, on the basis of this, in Section 96/A of the Hpt. In essence, the bank must retain 60 per cent of its year-end profits, and only 40 per cent of it can be used to pay dividends or variable remuneration. Payment restrictions should be maintained until the bank is able to meet these minimum requirements.

In line with the Basel recommendation, CRR2 also introduces the leverage ratio buffer requirement to be met by relevant G-SIls from 1 January 2023 (CRR2 was originally to introduce this requirement from January 2022, but due to the coronavirus pandemic, both the Basel Committee and the EU extended the implementation deadline by one year). There are no G-SIls in Hungary, but under the CRD, in the EU the Commission will have until June 2022 to examine whether the leverage ratio buffer requirement should be extended to O-SIls (Other Systemically Important Institutions). If the Commission proposes an extension, the EU Parliament and the Council may decide that the leverage ratio buffer requirement must also be met by O-SIls. This would currently mean a higher leverage ratio requirement for eight institutions in Hungary.

12 Directive 2013/36/EU of the European Parliament and of the Council of 26 June 2013 on access to the activity of credit institutions and the prudential supervision of credit institutions and investment firms 
Under the CRR2 leverage ratio regulation, national supervisory authorities may, in special circumstances, allow institutions not to include certain exposures to the central bank in the total exposure amount for a maximum period of one year. The consequence of this exemption, however, is that if a bank elects for the exemption for central bank exposures, the leverage ratio requirement will increase, i.e. the bank will have to meet a higher level than 3 per cent, and the degree of the higher requirement will depend on the amount of the exempted exposure.

The 2020 CRR 'quick fix' amendments to mitigate the economic impact of the coronavirus pandemic allowed national authorities to make use of this option even before the entry into force in June 2021. In fact, the ECB published its decision on this matter in September 2020. ${ }^{13}$ Given that the minimum leverage ratio requirement is not yet in force until June 2021, this has mainly helped ECBsupervised institutions to disclose more favourable leverage ratio data.

\subsection{Supervisory capital add-on requirement}

From December 2020, a new supervisory instrument in the CRD V ${ }^{14}$ (and in the Hpt. implementing it) is that the Magyar Nemzeti Bank (the Central Bank of Hungary, MNB) can formulate an additional own funds requirement and capital guidance for institutions in the event of excessive leverage risk. This capital requirement and capital guidance can be applied in addition to the capital requirement previously imposed under the SREP, and in practice means that the MNB sets a minimum for the institution, higher than the 3 per cent leverage ratio.

However, the capital add-on requirement imposed due to excessive leverage risk cannot be reflected in the supervisory capital add-on requirement on the 8 per cent risk-weighted asset value under the SREP, as due to the excessive leverage risk, only an imposition of an add-on on the leverage ratio can be formulated. Thus, in the case of the leverage ratio and the capital adequacy ratio, similar regulatory and supervisory instruments operate (Pillar 1 minimum requirement, capital buffer, supervisory capital add-on requirement, capital guidance), but these two sets of requirements operate in parallel, and there is no overlap between them. This new instrument may be particularly effective in countries with banks where the leverage ratio is an effective constraint.

\subsection{Relationship with other prudential regulatory instruments}

The current instruments for the prudential regulation of banks have evolved in a long process. Today, they can be said to form a coherent system that covers a wide range of banking activities and associated risks. At the same time, the business model, the market environment and the relevant risks associated with the activities

\footnotetext{
${ }^{13}$ https://www.bankingsupervision.europa.eu/press/pr/date/2020/html/ssm.pr200917 eaa01392ca.en.html ${ }^{14}$ Directive (EU) 2019/878 of the European Parliament and of the Council of 20 May 2019 amending Directive 2013/36/EU
} 
will affect which regulatory instrument is a bottleneck for a given bank. Most recently, the Basel Committee used year-end 2017 data to examine which prudential regulatory instrument was the most difficult for the 128 banks in the sample to meet (BCBS 2019). The survey found that the Tier 1 capital ratio was the strongest regulatory constraint for 35 per cent of banks, the NSFR (Net Stable Funding Ratio) for 15 per cent, the TLAC (Total Loss Absorbing Capacity, under the CRR: MREL ${ }^{15}$ ) for 12 per cent, the leverage ratio for 11 per cent and the LCR (Liquidity Coverage Ratio) for 6 per cent. As can be seen, while the leverage ratio is not the strongest regulatory instrument, it was still the strongest regulatory constraint for 11 per cent of banks. The leverage ratio regime is closely linked (in addition to capital adequacy) to other regulatory instruments, including, among others, the LCR rules, a possible future limitation of sovereign risks, the output floor and the MREL requirements, which also affect the effectiveness of the leverage ratio regime.

\subsection{1. $L C R$}

The Liquidity Coverage Ratio can be used to measure whether the bank holds a sufficient quantity and quality of liquid assets for the eventuality of a short-term (30-day) liquidity stress. ${ }^{16}$ The denominator of the ratio is the weighted amount of expected outflows within 30 days in the event of stress, and its numerator is the weighted amount of available liquid assets. ${ }^{17}$ Changes in the LCR may in some cases explain different movements in the capital adequacy ratio and the leverage ratio. If a bank invests its funds in government securities or other low-risk liquid assets to increase its liquidity, this may cause the LCR numerator to rise, while in capital adequacy, exposure with a 0 per cent or low risk weight causes no, or (in the case of a low positive weight) only a small, change. However, in the calculation of the leverage ratio, the same exposure is taken into account at full value, and it reduces its value. Of course, in this theoretical example, the movement of the LCR is considered in a very simplified way; only one component of it is considered. In addition to changes in liquid assets, the development of net outflows also plays a role in the evolution of the ratio, both via changes in the bank's liability structure (due to different outflow weights of liabilities) and via the development of inflows.

${ }^{15}$ MREL - Minimum Requirement for Own Funds and Eligible Liabilities

${ }^{16}$ https://www.mnb.hu/en/financial-stability/macroprudential-policy/the-macroprudential-toolkit/ instruments-addressing-liquidity-and-financing-risks

${ }^{17}$ The weights used for the calculation of the LCR are set out in Commission Delegated Regulation (EU) 2015/61, a text with EEA relevance supplementing Regulation (EU) No 575/2013 of the European Parliament and the Council with regard to liquidity coverage requirement for credit institutions. 
Movements in a direction similar to the above example (the LCR is rising, and the capital adequacy ratio and the leverage ratio are moving apart) are observed in the periods marked for banks 6,7 and 14, while for banks 15 and 16, we can see that with the LCR decline, the capital adequacy ratio and the leverage ratio are moving closer together (Figure 8).

\section{Figure 8 \\ Evolution of LCR, capital adequacy and leverage ratios (2018 Q2-2020 Q3)}

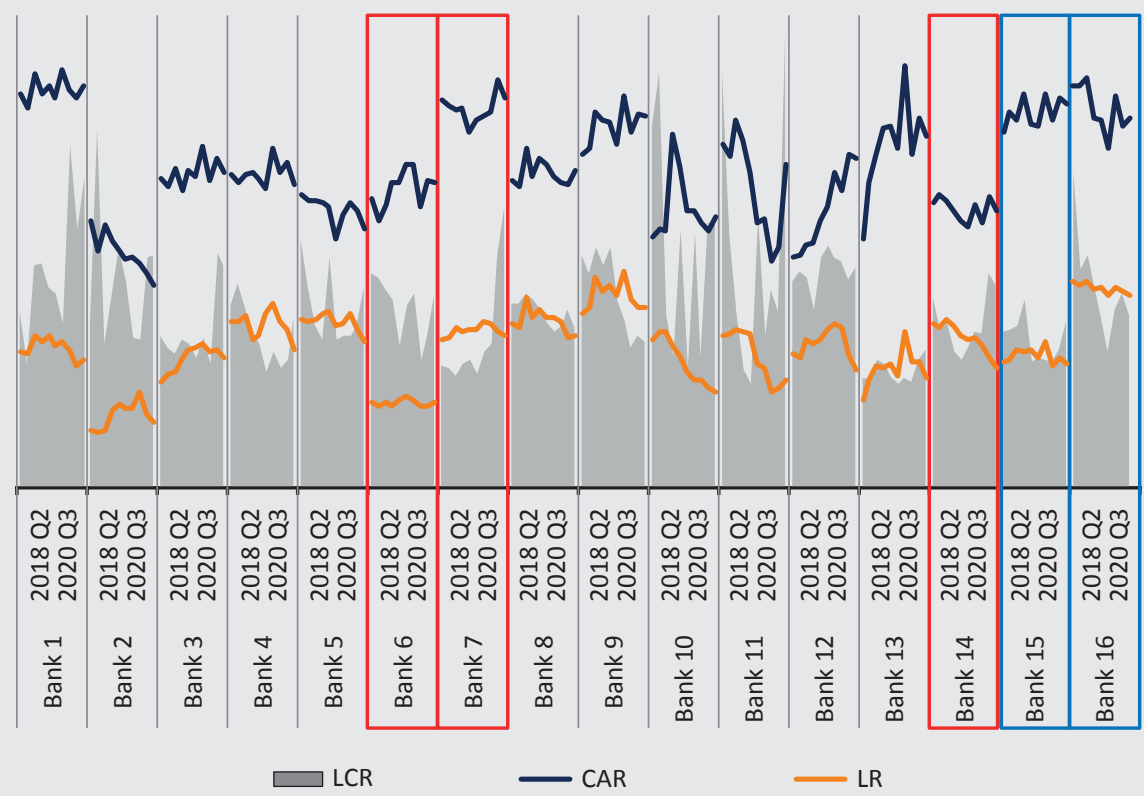

Note: To avoid identification, banks reporting outlier values are not shown in the figure. The exact values are not provided for data protection reasons, and the numbering of banks is different in the different figures.

Source: $M N B$, supervisory reporting

Although the primary purpose of introducing the leverage ratio is to ensure that banks have an adequate capital position, its impact on maintaining solvency cannot be entirely neglected either. As the leverage ratio requirement sets a threshold with regard to the Tier 1 capital minimum, it increases the proportion of funds that cannot be withdrawn in the event of a crisis and are available safely and permanently even in the case of a bank run. 


\subsubsection{Sovereign risks}

As the global financial crisis highlighted the dangers of too close a relationship between commercial banks and states, regulatory authorities - in particular the Basel Committee - have already made several attempts to restrict banks' sovereign exposures, i.e. risk-takings, mainly in the form of government securities or other forms of financing, towards individual states. The Basel Committee also published a separate discussion paper on this subject (BCBS 2018). In it, among other things, it suggested increasing the risk weight of sovereign exposures, imposing a capital add-on in the case of excessive concentration of sovereign risk exposures or possibly revising the exemption from large-exposure limit. In the end, however, no specific proposal was made for limiting sovereign risk exposures; nevertheless, it can be stated that the introduction of the leverage ratio is also partly suitable for limiting sovereign risk exposures. Namely, while these exposures are assigned a 0 or very low risk weight in the calculation of the capital adequacy ratio, in the leverage ratio, they have a 100 per cent weight in the calculation of the total exposure amount. Accordingly, a bank with a large proportion of government securities on its balance sheet is more likely to run into the 3 per cent leverage ratio limit than the minimum capital adequacy ratio requirement of 8 per cent.

\subsubsection{Output floor}

In December 2017, the Basel Committee further refined its recommendations on the prudential regime for banks, and in this context, it reintroduced a previously used instrument, the output floor. The output floor is designed to limit the capital requirement reduction - available through internal models - in the case of banks using internal models, in proportion to the capital requirement calculated under the standardised method.

In practice, this means that banks using internal models (basic or advanced internal rating-based approach) to calculate the credit risk capital requirement must also continue to calculate their capital requirement under the credit risk standardised method, and their final credit risk capital requirement should not be less than 72.5 per cent of the capital requirement calculated under the standardised method, even if internal model calculations resulted in a lower capital requirement. One of the main reasons for the introduction of the output floor was that the capital requirement calculations of banks using internal models showed significant differences in practice, and the capital requirement differences could not always be justified by empirical facts (e.g. portfolio PD differences, different business models).

Since the output floor limits the capital requirement reduction available to banks using internal models, and thus the average credit risk weight of the portfolio as a whole as well, it reduces the actual restrictive role of the leverage ratio. The leverage ratio is an actual constraint mainly for banks operating with low credit risk 
weights, while the output floor limits the extent to which the average risk weight can be reduced for banks using internal models.

This link has been identified and confirmed by the EBA Basel III monitoring reports (EBA 2020b). Analyses by the EBA showed that, without the application of the output floor, the capital adequacy requirements calculated by risk weights were the more stringent constraint for 71.7 per cent of the banks surveyed, while the leverage ratio was the more stringent regulatory instrument for 28.3 per cent of the banks. ${ }^{18}$ When the output floor is implemented, these ratios change as follows: the share of banks for which the capital adequacy ratio is the more stringent constraint remains at 71.7 per cent, the share of banks for which the leverage ratio is the constraint decreases to 12.3 per cent, and the share of banks for which the output floor will be the more stringent constraint is 16 per cent. The gradual introduction of the output floor from 2023 will therefore reduce the proportion of banks for which the leverage ratio is the actual constraint.

\subsubsection{MREL requirement standard}

The close relationship between the leverage ratio and the MREL is illustrated by the fact that the CRR set the minimum requirements for own funds and eligible liabilities for global systemically important institutions at 18 per cent of the riskbased calculated total risk exposure amount used to calculate the capital adequacy ratio, on the one hand, but at 6.75 per cent of the non-risk-based calculated total exposure amount used in the calculation of the leverage ratio on the other hand. As a consequence of this dual set of requirements, there may be banks for which the actual MREL requirement will not be the total risk exposure amount, but rather the value calculated on the basis of the non-risk-based total exposure amount. The level of the MREL requirement is thus also affected by the amount of leverage a bank is operating with.

Although there are no global systemically important institutions in Hungary, and the minimum MREL level for credit institutions is set by the resolution authority, the total exposure amount also has an impact on MREL compliance for these credit institutions. This is because, pursuant to the Resolution Directive ${ }^{19}$ and the Resolution $\mathrm{Act}^{20}$ implementing it in Hungary, the resolution authority sets the minimum requirement for own funds and eligible liabilities not only in proportion to the total risk exposure but also to the total exposure. Consequently, an increase in the total exposure amount may result in an increase in the minimum MREL level.

${ }^{18}$ The EBA's analysis also notes that the role of leverage ratio in this example is overestimated, as only the Pillar 1 requirements have been taken into account for capital adequacy requirements, which, in practice, are complemented by the Pillar 2 capital requirement and the capital buffer requirements.

${ }^{19}$ Directive 2014/59/EU of the European Parliament and of the Council of 15 May 2014 establishing a framework for the recovery and resolution of credit institutions and investment firms

${ }^{20}$ Act XXXVII of 2014 on the Development of the Institutional Framework Intended to Enhance the Security of Members of the Financial Intermediary System 


\subsection{Further decline in the role of Tier 2 capital}

Following the global financial crisis, there has been a clear regulatory trend towards reducing the role of Tier 2 capital that banks can take into account in own funds. One important lesson of the global financial crisis was that in the settlement of losses, Tier 2 capital items have only a limited capacity to absorb losses. This is partly because Tier 2 capital, unlike other own funds, may have maturity, and partly because it can actually be used to settle losses only in the event of liquidation of the bank.

Instruments that can be considered Tier 2 capital are usually subordinated loans with an original maturity of more than five years, where the lender agrees to be ranked last in the order of priority, senior to shareholders, in the event of liquidation of the bank. Although this provision poses a significant risk for the lender, as its claim is subordinated to that of other creditors, it also means that the bank can only use such an instrument in a liquidation procedure to settle losses.

This set of requirements was developed back at a time when banking crisis management procedures were quite underdeveloped and the main purpose of the regulation was to repay depositors their money even in the event of liquidation of the bank. However, the current banking regulation has recognised that winding up a bank is a long, costly process, which usually causes more losses than rescuing the bank as part of a comprehensive resolution process.

Regulatory changes over the past decade have therefore been geared towards improving the resolvability of banks (resolution authority and fund, setting minimum requirement for MREL liabilities). In such an approach, it is evident that the role of Tier 2 capital items in regulation should decline and that of higher-quality capital items should increase. This transformation is reflected in several regulatory items: its clearest item is the setting of minimum requirements for Core Tier 1 capital (4.5 per cent) and Tier 1 capital ( 6 per cent) within the capital adequacy ratio, as a result of which only one quarter of the total minimum requirement of 8 per cent can be covered with Tier 2 capital.

This decline in the role of Tier 2 capital is also reflected in the fact that the minimum leverage ratio requirement of 3 per cent - similarly to the basis of the largeexposure limit - has been set in proportion to the Tier 1 capital. The new prudential requirements for leverage ratio and large exposures to be met from June 2021 will therefore further reduce the role of Tier 2 capital, thereby encouraging banks to seek to include in their operation new capital instruments that can also be used to write off losses on a going concern basis. 


\subsection{The role of the business model}

Prior to the EU implementation of the Basel leverage ratio in the CRR, the EBA assessed the expected impact of its introduction and published a detailed report on the subject (EBA 2016). In that report, the EBA also discussed the business models for which it may be worth considering setting specific rules for banks in respect of calculating the leverage ratio. One such special business model is that of mortgage banks, which operate with a much lower average risk weight than commercial banks, as the loans they provide are mortgage-backed and thus have a low risk weight. Of the 12 mortgage banks in the sample at the time, in 2016, five still had leverage ratios below 3 per cent and another five had leverage ratios below 5 per cent.

As preliminary impact assessments showed that introducing the leverage ratio could be the most restrictive for the activities of mortgage banks, it was also suggested that a leverage ratio requirement of less than 3 per cent be set for mortgage banks, but this proposal was ultimately rejected.

The same EBA report also revealed that there is another business model that is more burdened than average by the leverage ratio requirement. Public development banks also operate with a low average risk weight, partly due to their client base and partly because of the public guarantee schemes related to their activities. Under the CRR2, such institutions are also not exempted from the leverage ratio regulation and not subject to a lower minimum requirement, but are nevertheless granted a significant relief: in calculating the total exposure amount, a public development credit institution ${ }^{21}$ does not need to take into account its claims on central governments, regional governments, local authorities or public sector entities in relation to public sector investments and promotional loans. Thus, regulating the leverage ratio cannot be a barrier to public sector development.

The 2016 EBA report on the leverage ratio contained a proposal for exempting central counterparties and central securities depositories operating as credit institutions from the leverage ratio regulation, but in the end the CRR only included the special feature that the initial margin on centrally-cleared derivative transactions received by institutions from their clients which they pass on to central counterparties should be excluded from the total exposure amount.

\footnotetext{
${ }^{21}$ This type of institution is defined in detail in Article 429a(2) of the CRR.
} 


\subsection{Disclosure}

Ever since the Basel II recommendation introduced disclosure requirements as the third pillar of the regulation in 2004, it has become common for the introduction of a new prudential rule to be accompanied by an extension of disclosure rules. Under the $C R R$, banks were already required to disclose data on the leverage ratio prior to the introduction of the 3 per cent minimum. Under the CRR2, credit institutions are required to disclose their leverage ratio and the total exposure amount on a semi-annual basis, and large institutions are also required to disclose the details of the calculation of the ratio.

\subsection{The leverage ratio as an alternative regulatory approach}

While the leverage ratio is a backstop-type instrument under the Basel Committee guidelines and the EU regulation, in the USA, the leverage ratio is also used as an alternative regulatory instrument. Since 1 January 2020, community banks supervised by the Office of the Comptroller of the Currency, the Federal Reserve, and the Federal Deposit Insurance Corporation have been allowed by law to comply only with the leverage ratio requirement, instead of the complex capital adequacy requirements calculated on the basis of risk weights. This option is available to banks where:

- the consolidated balance sheet total is below USD 10 billion;

- the ratio of off-balance sheet items to total assets is below 25 per cent; and

- the leverage ratio is above 9 per cent (temporarily reduced to 8 per cent due to the pandemic, with a minimum requirement of 9 per cent only from 2022).

This procedure is beneficial for banks because it makes it much cheaper for these institutions to comply with the legislation; they do not have to calculate their capital adequacy ratio using detailed rules and report it to the supervisory authority. In the event that a bank's leverage ratio falls below 9 per cent, the bank will be subject to a two-quarter transition period until it either brings its leverage ratio back to the required level or returns to the regulatory framework for the capital adequacy ratio.

This US measure is not contrary to the recommendations of the Basel Committee, as it only applies to large, internationally significant banks anyway. This option is available to a very high number of banks; based on the 2019 Q2 data, 4,581, i.e. 85 per cent of the 5,382 banks operating in the USA may have been able to meet the set of simplified compliance requirements (Loudis et al. 2020). Moreover, the financial developments in recent years have resulted in a trend of steady increase in the leverage ratio of US banks and overall, for 97 per cent of the banks eligible 
to join, the higher leverage ratio requirement of 9 per cent has resulted in a higher capital requirement than the capital adequacy requirements calculated on the basis of risk weights, so the transition also does not lead to a weakening of financial stability.

While this new system seems to be favourable for US banks, according to the data from September 2020, only less than a third of banks eligible to join had so far made use of the simplified compliance option. The main reason for this was that they found the resulting cost savings insufficient and the large inflow of deposits had reduced their leverage ratio and made their ability to meet the minimum requirement on a sustained basis uncertain (Duren - Clark 2020).

By using the new direction and its experience, in the longer term, even EU policymakers may consider the possibility of moving to a simplified capital requirement regulation, as in the EU there are also a great many small institutions for which a simpler calculation method could lead to cost savings. For example, only six ${ }^{22}$ of the banking groups operating in Hungary have a balance sheet total of more than HUF 3,000 billion (USD 10 billion), i.e. such a measure could mean simpler requirements for many banks in Hungary as well; furthermore, in a number of other EU countries (especially in those with smaller cooperative banks), this may mean an even higher ratio to the number of banks.

\section{Summary}

The introduction of the leverage ratio is one of the several regulatory responses to the global financial crisis. From June 2021, the set of EU requirements based on the recommendations of the Basel Committee will be a mandatory minimum requirement in Hungary as well, under the directly applicable EU regulation. The leverage ratio requirement in its current form only complements the capital adequacy requirements calculated on the basis of risk weights, but it seems to be an effective instrument to prevent banks from becoming overleveraged, thereby improving the resilience of the banking system and strengthening financial stability. The leverage ratio is also closely linked to other instruments of prudential regulation, in particular liquidity requirements, MREL requirements and the output floor, and can effectively contribute to appropriately correcting for possible underestimation of risks in the calculation of the capital adequacy ratio. However, regulators should also bear in mind that while an excessively high leverage ratio requirement may be effective in raising the level of own funds in the banking system, it may contribute to financial services becoming more expensive or to their moving outside the banking

\footnotetext{
${ }^{22}$ Based on the data from 31 December 2020
} 
system, and thus the minimum level of leverage ratio should only be changed on the basis of thorough impact studies.

The business model of banks has a significant impact on how they are affected by the introduction of the new requirement. The leverage ratio is expected to be an actual constraint for banks operating with a low average risk weight and a significant proportion of Tier 2 capital. These banks can achieve compliance with the new requirement primarily by raising a new Tier 1 capital or by changing their business model. Other measures related to the leverage ratio, in particular the methods for supervisory imposition of capital add-on and capital guidance due to the risk of excessive leverage, are still under development; thus, the actual impact of the leverage ratio can be effectively estimated once these supervisory procedures are in place and integrated into the supervisory processes. It is quite possible that through the use of practical experience even the leverage ratio regime will change in the future so that this new requirement can act as an effective constraint for a wider range of banks to curb excessive risk-taking. The changes may not only concern the minimum level of leverage ratio, as - in their own right - the changes to certain detailed rules for the calculation method (e.g. exemptions from inclusion in total exposure amount) may also be such as to allow regulatory authorities to influence the way banks operate.

\section{References}

Barth, J.R. - Miller, S.M. (2018): Benefits and costs of a higher bank "leverage ratio". Journal of Financial Stability, 38(October): 37-52. https://doi.org/10.1016/j.jfs.2018.07.001

BCBS (2010): The Basel Committee's response to the financial crisis: report to the G20. Basel Committee on Banking Supervision, October. https://www.bis.org/publ/bcbs179.pdf

BCBS (2017): Basel III: High-level summary of Basel III reforms. Basel Committee on Banking Supervision, December. https://www.bis.org/bcbs/publ/d424_hlsummary.pdf

BCBS (2018): The regulatory treatment of sovereign exposures. Discussion paper, Basel Committee on Banking Supervision, 9 March. https://www.bis.org/bcbs/publ/d425.pdf

BCBS (2019): Survey on the interaction of regulatory instruments: results and analysis, Working Paper 35, Basel Committee on Banking Supervision, March. https://www.bis. org/bcbs/publ/wp35.pdf

Brei, M. - Gambacorta, L. (2014): The leverage ratio over the cycle. BIS Working Papers No 471, Bank for International Settlements, November. https://www.bis.org/publ/work471. pdf 
De Larosière, J. (2009): The High-Level Group on Financial Supervision. Report, The de Larosière Group, 25 February. https://ec.europa.eu/economy_finance/publications/pages/ publication14527_en.pdf. Downloaded: 25 February 2021.

Duren, C. - Clark, R. (2020): More than 2,700 community banks say 'no thanks' to reg relief. S\&P Global Market Intelligence, 10 September. https://www.spglobal.com/ marketintelligence/en/news-insights/latest-news-headlines/more-than-2-700-communitybanks-say-no-thanks-to-reg-relief-60270427. Downloaded: 22 February 2021.

EBA (2016): Report on the Leverage Ratio Requirements under article 511 of the CRR. EBA-Op-2016-13, European Banking Authority, August. https://www.eba.europa.eu/ sites/default/documents/files/documents/10180/1360107/3889de6a-42d8-4bea-8ccbca7750085fbb/EBA-Op-2016-13\%20\%28Leverage\%20ratio\%20report\%29.pdf?retry=1

EBA (2020a): Risk Assessment of the European Banking System. European Banking Authority, December. https://www.eba.europa.eu/sites/default/documents/files/document_library/ Risk\%20Analysis\%20and\%20Data/Risk\%20Assessment\%20Reports/2020/December\%20 2020/961060/Risk\%20Assessment_Report_December_2020.pdf

EBA (2020b): Basel III Monitoring Exercise - Results Based on Data as of 31 December 2019. EBA/Rep/2020/33, European Banking Authority, December. https://www.eba.europa.eu/ sites/default/documents/files/document_library/Publications/Reports/2020/960797/ Basel\%20III\%20monitoring\%20report\%20-\%20Dec\%202020.pdf

ESRB (2014): Is Europe Overbanked? Reports of the Advisory Scientific Committee, No. 4/ June 2014, European Systemic Risk Board. https://www.esrb.europa.eu/pub/pdf/asc/ Reports_ASC_4_1406.pdf

Kenaissi, M. - Gimpelewicz, M. (2017): Taking a long hard look in the mirror: should the leverage ratio reflect Pillar 2? BankUnderground, 27 April. https://bankunderground. co.uk/2017/04/27/taking-a-long-hard-look-in-the-mirror-should-the-leverage-ratio-reflectpillar-2/. Downloaded: 18 February 2021.

Loudis, B. - Nguyen, D. - Wix, C. (2020): Analyzing the Community Bank Leverage Ratio. FEDS Notes, May 26. https://www.federalreserve.gov/econres/notes/feds-notes/analyzing-thecommunity-bank-leverage-ratio-20200526.htm

Marquardt, R. - Blåvarg, M. (2010): The socio-economic consequences of introducing a leverage ratio for banks, Handelsbanken's Series of Small Publications No. 28, April. https://www.handelsbanken.com.sg/shb/inet/icentsv.nsf/vlookuppics/investor_relations_ en_socio-econ_conseq_of_lev_ratio_apr10_en/\$file/socio-ecomomic_consequences_of_ leverage_ratio_april_2010.pdf. Downloaded: 26 February 2021. 
Newell, J. (2016): Doing the Math on the Leverage Ratio. Bank Policy Institute, 14 July. https://bpi.com/doing-the-math-on-the-leverage-ratio/. Downloaded: 23 February 2021.

Smith, J.A. - Grill, M. - Lang, J.H., (2017): The leverage ratio, risk-taking and bank stability, ECB Working Paper Series No 2079/, June 2017, European Central Bank. https://www.ecb. europa.eu/pub/pdf/scpwps/ecb.wp2079.en.pdf?97048db54786167f5a45a6426ffd80d7

Smith, J. (2020): The leverage ratio: a balance between risk and safety. BankUnderground, 6 October. https://bankunderground.co.uk/2020/10/06/the-leverage-ratio-a-balancebetween-risk-and-safety/. Downloaded: 24 February 2021. 